Review Article

\title{
A Review of the Structural Fire Performance Testing Methods for Beam-to-Column Connections
}

\author{
Noor Azim Mohd. Radzi, Roszilah Hamid $\mathbb{D}^{D}$, Azrul A. Mutalib $\mathbb{D}$, and A. B. M. Amrul Kaish
}

Department of Civil Engineering, Faculty of Engineering and Built Environment, Universiti Kebangsaan Malaysia, 43600 UKM Bangi, Selangor D. E., Malaysia

Correspondence should be addressed to Roszilah Hamid; roszilah@ukm.edu.my

Received 12 August 2021; Revised 4 October 2021; Accepted 8 October 2021; Published 3 November 2021

Academic Editor: Wenjie Ge

Copyright (C) 2021 Noor Azim Mohd. Radzi et al. This is an open access article distributed under the Creative Commons Attribution License, which permits unrestricted use, distribution, and reproduction in any medium, provided the original work is properly cited.

\begin{abstract}
The structural fire performance tests for beam-to-column connections are critical in determining their fire performance at high temperatures. The current standard fire testing methods provide the procedures for establishing the fire resistance of each construction element exposed to a standard fire. However, these methods cannot verify the fire behaviour of the connections between building elements. Researchers have performed numerous fire tests on beam-to-column connections despite the lack of structural fire performance testing methods. This paper presents a comprehensive literature review of the structural fire performance testing methods for beam-to-column connections. The major areas in this review are travelling fires, development of travelling fires on beam-to-column connections, fire testing considerations, fire testing criteria, recent fire testing, and loading applications. This paper identifies the key issues and challenges of the structural fire performance testing methods for beam-tocolumn connections. Finally, this paper provides recommendations and discusses the way forward for structural fire performance tests on beam-to-column connections.
\end{abstract}

\section{Introduction and Objectives}

Structural fires occur primarily in residential, commercial, or community-based buildings. Fire exposures could significantly reduce the strength, insulation, and integrity of a building's main structural elements $[1,2]$. The beam-tocolumn connections are critical elements of any building structure $[3,4]$. The collapse of the World Trade Centre and the results of the Cardington full-scale building fire tests in the United Kingdom demonstrate that beam-to-column connections are vulnerable during the heating and cooling phases of fire $[5,6]$. Therefore, it is critical to ensure the connections fulfil the requirements for fire safety and durability $[3,7,8]$.

Researchers are conducting structural fire performance tests on beam-to-column connections to determine their fire performance at high temperatures. The fire tests provide the critical thermal parameters for beam-to-column connections, including failure patterns, crack developments, moment-rotation-temperature curves, load-deflection curves, stress-strain curves, internal temperature distributions, residual strength, and physical damages [9]. The most widely used fire test specifications are ASTM E119 [10] and ISO 834 [11]. ASTM E119 specifies the test method for evaluating the duration building elements can contain a fire, retain the building's structural integrity, or exhibit both properties during a predetermined test exposure. ISO 834 specifies the test for determining the fire resistance of construction elements when exposed to standard fire conditions. However, the standard fire testing methods do not have the procedures for verifying the fire behaviour of connections between building elements $[10,11]$. Instead, the fire tests focus on vertical building elements, such as walls, partitions and columns, and horizontal building elements, such as floors, roofs, beams, and girders. In addition, the fire tests do not consider the effects of horizontal and vertical travelling fires and only use the standard fire curves with uniform burning and homogenous temperature conditions.

Despite the lack of structural fire performance testing methods for beam-to-column connections, researchers have conducted numerous fire tests on rigid, semirigid and 
pinned beam-to-column connections $[12,13]$. Most largescale fire tests involved steel and composite beam-to-column connections because of the greater fire risk of these connections than concrete materials. The large-scale tests demonstrated the performance on a realistic scale when subject to the actual conditions of applied thermal and static loadings to comply with the regulatory requirements [14]. However, there has been a shift to focus on large-scale nonstandard fire testing using real fire rather than the standard fire $[15,16]$. The standard fire testing furnace is unrealistic for most real structures and fundamentally incapable of rationally simulating several essential and interrelated anticipated behaviours observed in actual building fires. The design of structural fire protection methods based on the standard fire tests of a single element does not account for the connection behaviour or the entire structure [17].

With the increasing conflicts in the standard fire testing methods for beam-to-column connections, researchers need to understand the critical elements in the fire tests. This paper presents a comprehensive literature review of the structural fire performance testing methods for beam-tocolumn connections. Figure 1 illustrates the framework of this review paper. In stage one of the literature review, the authors searched and screened the Web of Science and Scopus databases for the literature concerning building fires and fire testing of beam-to-column connections and defined the critical concept in building fires, including travelling fires and standard fires. The review includes the consideration in fire testing, namely, the time-temperature fire curves, testing methods, and cooling phase. In stage two, the authors reviewed and extracted the fire testing methods and data from previous studies and summarised the main criteria for fire testing of beam-to-column connections. In stage three, the authors identified the key issues and challenges in the structural fire performance testing methods for beam-tocolumn connections and analysed and synthesised the fire testing data. Finally, this paper provides the recommendations and presents the way forward for the structural fire performance tests of beam-to-column connections to help steer future research in structural fire engineering, particularly large-scale experimental research.

\section{Fire Testing of Beam-to-Column Connections}

2.1. Travelling Fires. In buildings with large, open compartments, the fire does not burn simultaneously throughout the entire floor plate of the structure. Instead, the fire tends to travel horizontally and vertically as the flames spread by igniting the fuel in their path and burning a limited area at any one time $[18,19]$. This condition, known as travelling fires, is different from the commonly used fire scenarios for the structural design of modern buildings. The traditional methods assume uniform burning and homogenous temperature conditions throughout a compartment, regardless of its size $[20,21]$. In addition, the methods for validating the parameters and standard fires using small fire compartments, better known as "black boxes," reduce the accuracy of the predicted structural fire behaviour [22].
Stern-Gottfried et al. [20] introduced the pioneering method for estimating the temperature of compartment travelling fires. The large firecell method (LFM) [23] developed in 1996 employs specific fire models to determine the temperature-time relationships for travelling fires through a firecell. However, LFM is primarily a research tool used for single element checks in a design. The travelling fires methodology (TFM) [24, 25], developed in 2012, calculates the fire-induced thermal field such that it is physically based, is compatible with the subsequent structural analysis, and accounts for the fire dynamics. This method uses two temperature fields to represent the gas temperature in a compartment. The near field $\left(T_{\mathrm{nf}}\right)$ is the high temperature in the flaming region of the fire that is exposed directly to the flames. The far field $\left(T_{\mathrm{ff}}\right)$ is the cooler temperature for the smoke in the rest of the compartment, which is exposed to hot combustion gases but experiences less intense heating than from the flames. TFM is effective in providing a flexible technique with an extensive range of possible fires in any compartment. In 2015, Rackauskaite et al. [21] developed the improved TFM (iTFM) for studying the effect of nonuniform heating associated with the travelling fires by investigating the peak temperature location along the fire path. They found that the peak temperature in the compartment occurs primarily towards the end of the fire path. However, Dai et al. [19] stated that, despite the experimental and theoretical works carried out during the past twenty years, more practical large-scale travelling fires experiments are required to expand the knowledge on travelling fires.

The structural response of travelling fires has a significant impact on structural performance. Bailey et al. [26] found that progressive horizontal spreading fire enhanced some of the distortions caused by the fire compared with simultaneous burning across the same compartment range. Ellobody and Bailey [27] found that horizontally travelling fires influence time-deflection behaviour. Law et al. [18] observed that the most severe structural response caused by horizontal travelling fires is approximately $25 \%$ of the floor plate in size. Roben et al. [28] found that the interfloor time delay influenced the structural behaviour in the vertical travelling fires that involve large and multiple floors. They recommended considering several rates of spread and ensuring the structural integrity for each rate to identify a worst-case rate of vertical fire spread. Behnam [29] found that structures exposed to nonuniform fires are more susceptible to failure than those exposed to uniform fires. The fire resistance of structures towards travelling fires is 91 minutes compared with the 140-minute resistance towards uniform temperature. Behnam and Ronagh [30] recommended implementing more provisions in the codes for postfire structure and the appropriate rate of vertical spread of fire between floors. Further, Jiang et al. [31] demonstrated that slow fires could cause partial collapse, whereas fast travelling fires could cause global collapse. The travelling speed has a considerable impact on the failure sequence of columns, damage range, and collapse mode of the structures. 


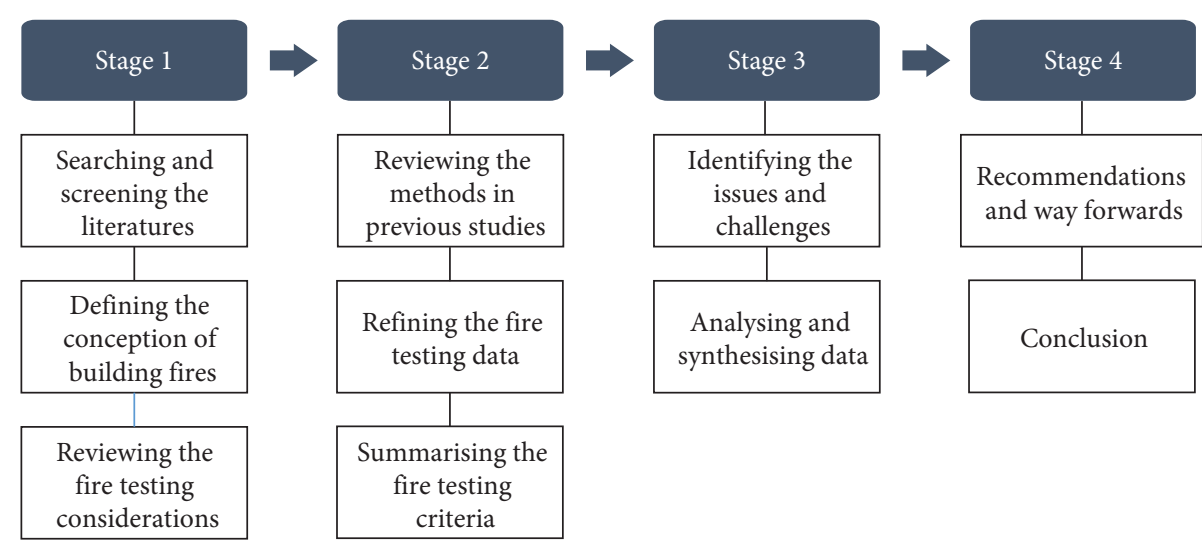

FIgURE 1: Framework of the review paper.

\subsection{Development of Travelling Fires on Beam-to-Column} Connections. Figure 2 shows the temperature development due to localised horizontal and vertical travelling fires for pinned concrete beam-to-column connections. Figure 2(a) shows the flame spread by igniting the fuel and burning the middle of the lower floor. Point A is the near field with the highest temperature, while point $B$ is the far field with a cooler temperature. Once the local fuel is completely burnt, the near field travels horizontally to a new area from point $A$ to B. Figure 2(b) shows the near field for the beam-tocolumn connection (point B) exposed to the highest temperature. The fire continues to burn at the same rate until all the fuel is burnt. At this time, the local fuel at point $\mathrm{A}$ is completely burnt and the structure begins to cool, and the fire damage sustained by the structure, such as deflection, crack, and spalling, becomes apparent. The fire travels vertically to the upper floor from point $B$ to $C$ through a damaged structural joint, unprotected service ducts, combustible façade materials, and unprotected openings, such as non-fire-rated windows. The flame movement increases the temperature at the top, creating the far field. Figure 2(c) shows a similar process, where point $\mathrm{C}$ is the near field exposed to the highest temperature. The near field travels horizontally to the middle of the upper floor. The local fuel at point B burns out, and the structure begins to cool.

Figure 2(d) shows the temperature-time curves for points $\mathrm{A}, \mathrm{B}$, and $\mathrm{C}$ during the fire. Vertical travelling fires spread for a longer duration than horizontal travelling fires due to structural constraints. According to Law et al. [18], the maximum temperature in the near field region is between 800 and $1000^{\circ} \mathrm{C}$ for a small fire and $1200^{\circ} \mathrm{C}$ for larger enclosure fires. They chose the $1200^{\circ} \mathrm{C}$ maximum value to represent the worst-case scenario of the fire. The maximum temperature of the near field region was calculated using the simple ceiling jet correlation developed by Alpert [32]:

$$
T_{\max }-T_{\infty}=\frac{5.38(\dot{\mathrm{Q}} / r)^{2 / 3}}{H},
$$

where $T_{\max }$ is the maximum temperature within the ceiling jet $\left({ }^{\circ} \mathrm{C}\right)$, To is the ambient temperature $\left({ }^{\circ} \mathrm{C}\right), \dot{Q}$ is the heat release rate $(\mathrm{kW}), r$ is the distance from the centre of the fire $(\mathrm{m})$, and $\mathrm{H}$ is the floor to ceiling height $(\mathrm{m})$. Clifton [23] stated that the temperatures for the preheating and delayed cooling (after the burnout) periods, which is exposed to hot combustion gases but experiences less intense heating than from the flames, was taken to be between 200 and $675^{\circ} \mathrm{C}$. Subsequently, the preheating and delayed cooling periods changed to the temperature between 400 and $800^{\circ} \mathrm{C}$. The far field temperature was calculated using the following:

$$
T_{f f}=\frac{\left[\int_{r_{n f}}^{r_{f f}}\left(T_{\max }\right)^{4} \mathrm{~d} r\right]^{1 / 4}}{\left(r_{f f}-r_{n f}\right)^{1 / 4}},
$$

where $\mathrm{T}_{\mathrm{ff}}$ is the far field temperature $\left({ }^{\circ} \mathrm{C}\right), \mathrm{r}_{\mathrm{nf}}$ is the distance between the end of the near field $(\mathrm{m}), \mathrm{r}_{\mathrm{ff}}$ is the distance between the end of the far field ( $m)$, and $r$ is the distance from the centre of the fire $(m)$. The temperature fields calculated at points $\mathrm{A}, \mathrm{B}$, and $\mathrm{C}$ are applied to both concrete and steel structures through heat transfer analyses. These analyses consider the temperature of steel rebar within concrete or steel beams to determine structural performance.

2.3. Fire Testing Considerations. Even though building fires are horizontal and vertical travelling fires, most fire tests on beam-to-column connections employed the standard timetemperature fire curves as a reference. Figure 3 shows a comparison of the real fire time-temperature curves and the standard time-temperature fire curves. The real fire timetemperature curves have three phases, growth, burning (flashover and fully developed), and decay (cooling) [34, 35]. The most widely employed time-temperature curve for real fire exposure is the "Swedish" fire curve representing different natural fire environments $[34,36]$. Real fires begin with the burning of one item, and the fire gradually spreads to other nearby objects and grows in size and intensity [36]. The standard time-temperature fire curves (Figure 3) are developed in growth and burning stages continuously over time. The ASTM E119 and ISO 834 practices are similar for building fires. Both fire curves are dependent on the burning rate of the materials present in the building materials and contents. They represent a severe fire expected in a typical building environment but does not represent all potential fire scenarios. Even though there are many studies on the 


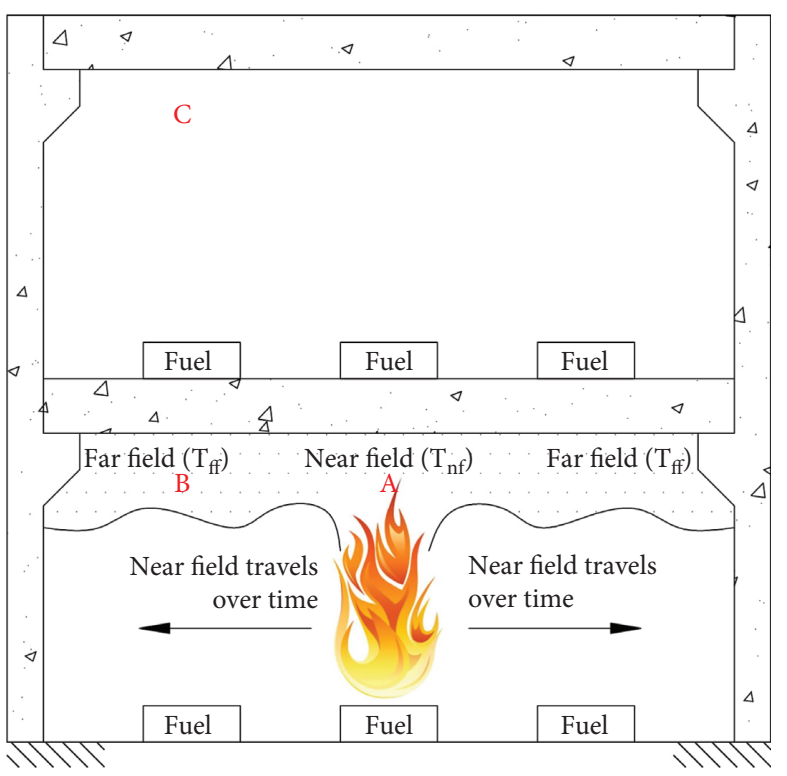

(a)

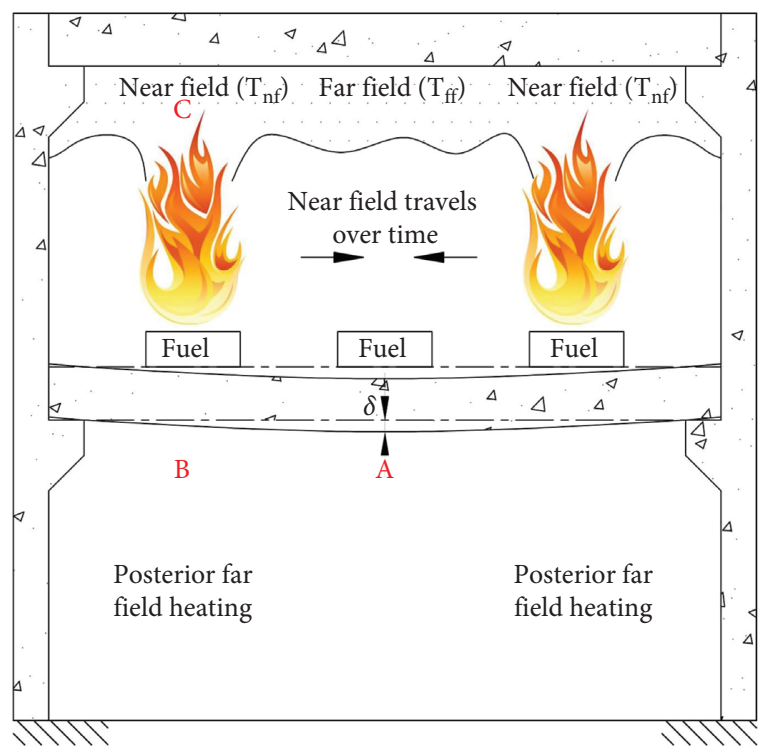

(c)

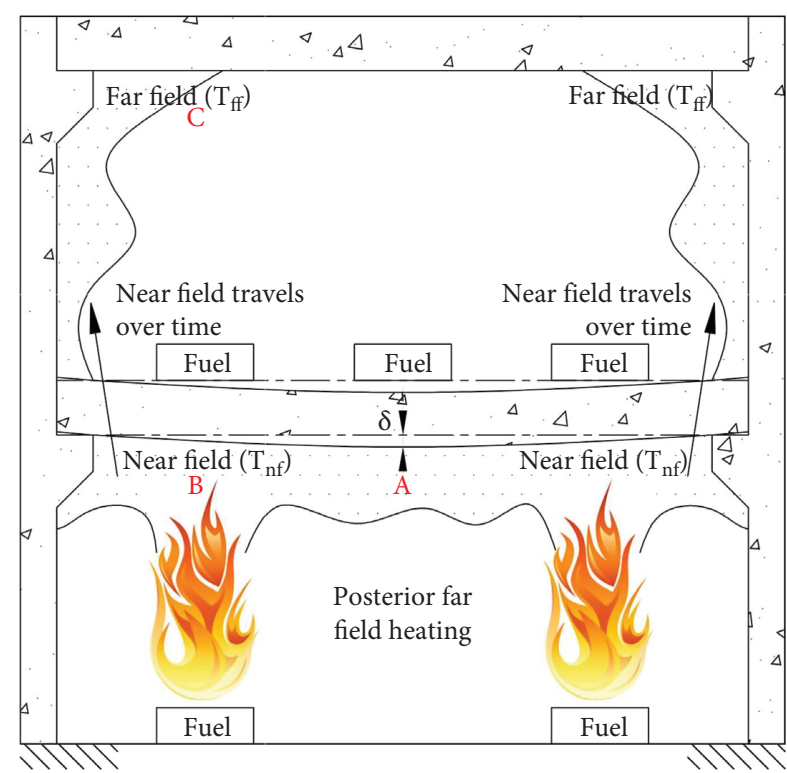

(b)

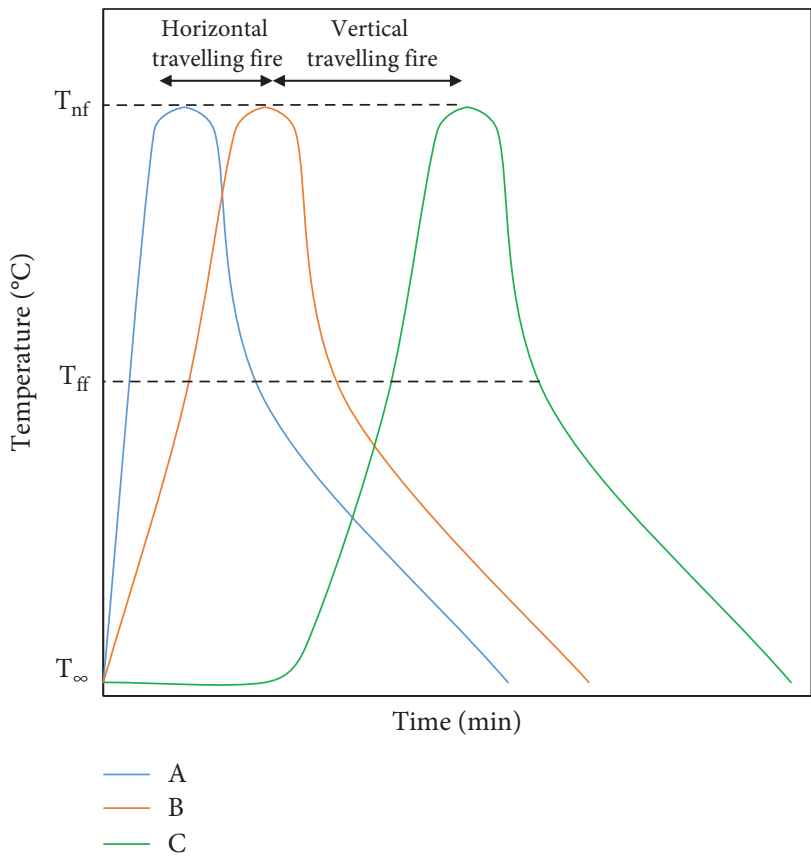

(d)

FIgURE 2: Temperature development due to localised travelling fire: (a) horizontal, (b) vertical, (c) horizontal, and (d) temperature-time curves at $\mathrm{A}, \mathrm{B}$, and $\mathrm{C}$.

heating phase of a building fire, the effects of the cooling phase on structures are not well-understood [33]. Structural vulnerability increases during the cooling phase [37].

In addition to selecting the appropriate fire curve, researchers considered several factors to address the lack of structural fire performance testing methods for beam-tocolumn connections. Researchers need to understand the purpose of connection testing. The connection testing performed at ambient temperature sought to determine the joint bending moment-rotation characteristics since the bending moment is the primary action acting on the joints.
During fire exposure, the connection testing sought to determine the combination of axial force, shear force, and bending moment that vary throughout the fire exposure. The researchers then selected the time-temperature fire curves for the fire tests and the load condition based on the specified fire exposure period. Finally, they compared the postfire results against the required performance criteria for the beam and column elements. In all assessments of structural fire resistance, the temperature developments in a structure should be determined, followed by evaluating the structural behaviour at elevated temperatures [38]. 


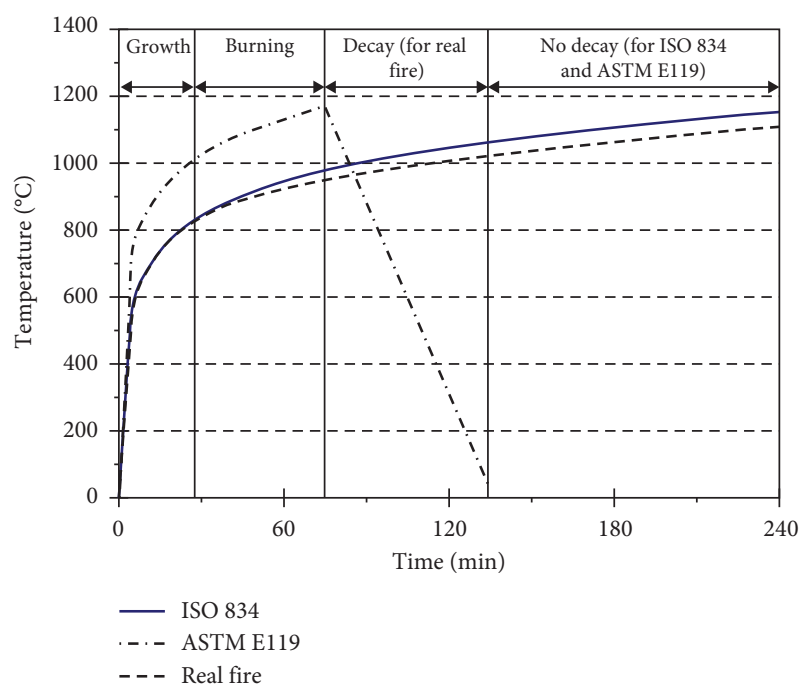

FIgURE 3: A comparison of real fire time-temperature curve with standard time-temperature fire curve (ASTM E119 and ISO 834) [34].

2.4. Fire Testing Criteria. Figure 4 summarises the fire testing criteria for beam-to-column connections from the test objective and performance criteria adopted in previous studies. Criteria 1 to 7 are the materials, type of connection, method of connection, boundary condition (constraints), fire source, type of analysis, and load application. The beam and column specimens are concrete, steel, composite, or timber. The beam-to-column connections are rigid, semirigid, or pinned, depending on the connection stiffness. The beam and column elements were assembled using either a wet, dry, or semidry method, and the boundary condition (constraints) for support is a roller, pin, or fixed end. The fire source for producing the heat is an electrical furnace, gas burner, and flexible ceramic pad. Most previous research analysed fire exposure together with static or cyclic load. The load applied in the different stages are preloading, concurrent loading (during the fire tests), and postfire loading.

2.5. Recent Fire Tests. Table 1 summarises the outcomes of the fire tests on beam-to-column connections conducted from 2007 to the present using the seven fire test criteria listed in Figure 4. More than 50\% of the articles on the beamto-column connections fire tests were published in the last five years, suggesting that researchers focused on this area of research.

Concerning Criteria 1, researchers have performed many fire tests on the beam-to-column connections fabricated from steel and composite materials due to the greater fire risk of these connections than those from concrete materials (Table 1). Steel and composite materials experience catenary action that may fracture the connections and exert additional forces on the columns at very high temperatures [47]. Among the mode of failure observed in the fire tests on steel and composite materials is the yielding of the endplate, yielding of the column flange, bolt (thread) stripping, bolt fracture, fracture of the endplate and slab cracking, and pulling out of the shear studs for composite connections. However, the literature showed that concrete connections also have a high fire risk [12]. The researchers observed that the concrete connections in the structures damaged in the fire tests could resist significant moments even at large deformations. Besides, the growing use of engineered timber structures in the design of high-rise buildings (more than five-storey high) presents fundamental challenges for structural fire-safe design $[48,49]$. The fire behaviour of the connections often limits the fire performance of heavy timber structural systems. The improved fire performance of dowelled timber connections could significantly improve the fire performance of whole timber structures $[50,51]$.

Criteria 2 classifies the connections with low stiffness as pinned, and those with high stiffness are fixed or rigid connections (Table 1). The connections with partial strength and have a certain degree of rotational stiffness are classified as semirigid. The columns are stronger than the beams and the connections and act as elastic restraints during the fire tests, where the failures are dependent on the beams or connections [38-40]. For the concrete connections, the tension reinforcement at the support is carried through to the connections and effectively overlapped [42]. Precast concrete connections, such as corbel and hybrid, are semirigid connections [46].

Concerning Criteria 3, most steel connections were assembled using the dry method, and the composite and concrete connections were assembled using the wet method (Table 1). For precast concretes, a combination of dry and wet methods is considered a semidry method. Wet-assembled partially precast structures were designed to emulate cast-in-situ concrete structures with rigid connections through the cast-in-place concrete pouring of the joints. In addition, the use of mechanical devices such as bolts and welds to connect the dry-assembled structures avoids the need for in-situ concrete pouring.

Regarding Criteria 4, the thermal behaviour of the connection is influenced by the boundary conditions (constraints) of the beam and column (Table 1). The fire is treated as a thermal boundary condition when focusing on structural performance [52]. The structural model of a fire test can be assigned as a partial element, single element, subframe assembly, transiently simulated restrained assembly, and full-scale structure [53]. The simply supported and cantilever setups are most often adopted boundary conditions for the beam constraints. In the simply supported setup, the beam midsection was fixed in the axial direction, which effectively prevents rotation about the two principal axes of the beam cross section but allows the beam to twist about its longitudinal axis [43]. However, the members in a framed structure behave differently from the isolated members simply supported at both ends because the structural continuity imposes a finite amount of restraint to the end of any connected member [39]. In the cantilever setup, also known as subassemblies, the ends of the beam are free. According to Raouffard and Nishiyama [1], the degree of structural indeterminacy of the test specimens is reduced by removing the midsection of the beam and turning it into 


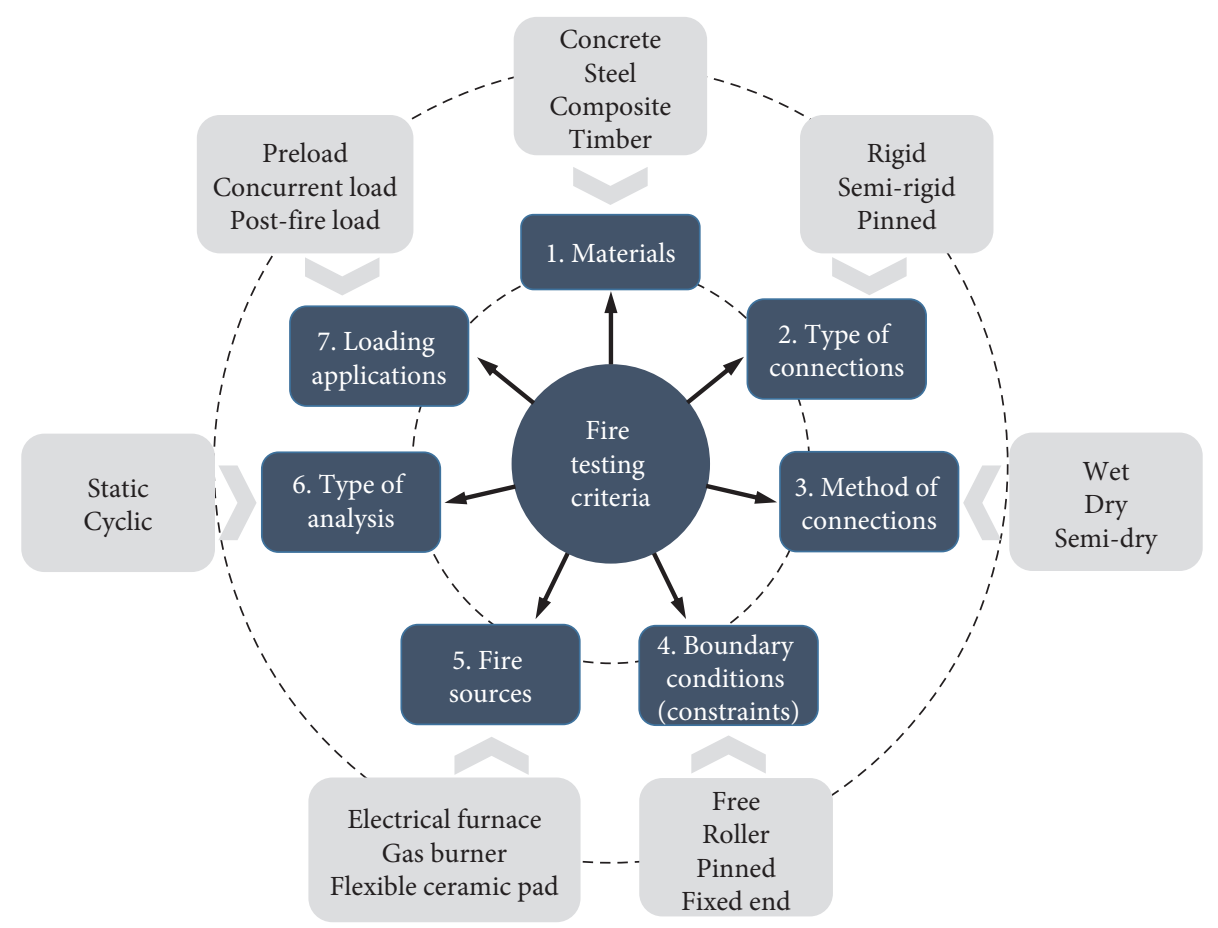

FIgURE 4: The fire testing criteria for beam-to-column connections.

two separate cantilever beams. For the column constraints, most of the top and bottom ends are restrained from lateral movement to ensure a good distribution of the axial column load and provide axial restraint to the beam [38]. As a result, the end of the column is free to move in the longitudinal direction. Another boundary condition is where both ends of the column are hinged, with an axial compressive load applied on the top [54].

For Criteria 5, most fire tests use a standard furnace to simulate the fire exposure (Table 1). Most research adopted the ISO 834 and ASTM E119 fire curves using a furnace. The loading points are outside the furnace. The items installed in the furnace such as the steel bar (to prevent the loading jacks from sliding towards each other) $[38,41]$, the top flange of the steel beam $[38,40]$, the sides and top of the reinforced concrete (RC) slab, and the upper part of the square concrete-filled steel tube (CFST) column were wrapped with a layer of ceramic fibre blanket before igniting the furnace.

Table 1 shows that, for Criteria 6, most analyses of the structural fire performance tests for beam-to-column connections used static load instead of cyclic load. Researchers have performed many static loading tests to investigate the progressive collapse resistance of RC moment frames during a fire [55]. Researchers also analysed reverse cyclic loadings to evaluate seismic behaviours with fire effects.

It is worth noting that Table 1 shows significant inconsistencies for Criteria 7. The load was applied either in the preloading (structural response at ambient conditions), concurrent loading (thermo-mechanical response during fire exposure), or postfire loading (residual response after cooling down) stage, or a combination of these stages. The following section will describe the loading application criteria in detail.
2.6. Load Applications. Two types of loading were used to simulate the maximum load condition following ASTM E119 and ISO $834[10,11]$. ASTM E119 uses the superimposed load, while ISO 834 uses the service load. The loads are defined differently. Service load is the maximum load intensity expected during the life span of the structure. It is a combination of unfactored dead load and unfactored live load. Superimposed load, also known as superimposed dead load, considers the weight of the nonstructural and semipermanent members, including the facade members, floor cover, suspended ceiling, and ductwork. It does not take into account the live load and thus is less than the service load. However, ASTM E119 states that superimposed loads can consider the maximum load condition allowed under each nationally recognised structural design criteria.

Figure 5 presents a summary of the load application and performance criteria during the beam-to-column connections fire tests. The figure shows the ambient, growth and burning, and decay phases. In the ambient phase, the specimens were preloaded with a load equal to the initial crack load or loaded based on the load ratio before carrying out the fire tests. In the growth and burning phase, the load was applied to the specimens either constantly or gradually. The constant load is the superimposed or service load stated in the ASTM E119 and ISO 834, while the gradual load is the incremental load applied to the specimens until they fail. The load application criteria were based on the research objectives. Table 2 shows that investigation of thermal behaviour, thermal interaction and strength reduction requires applying a constant load to the specimens and terminating the test at the performance criteria limit. Table 3 shows that determination of failure load and maximum deformation (deflection, expansion, or contraction) requires applying 


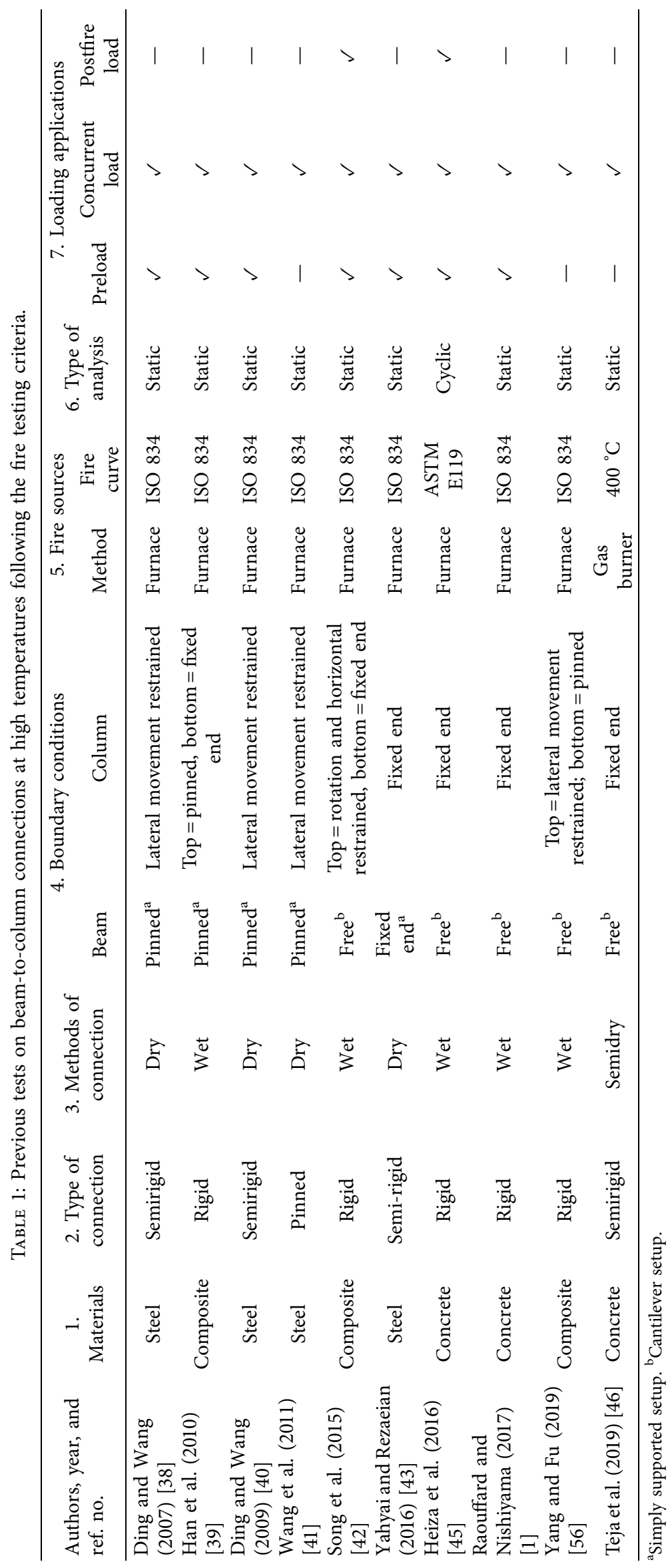




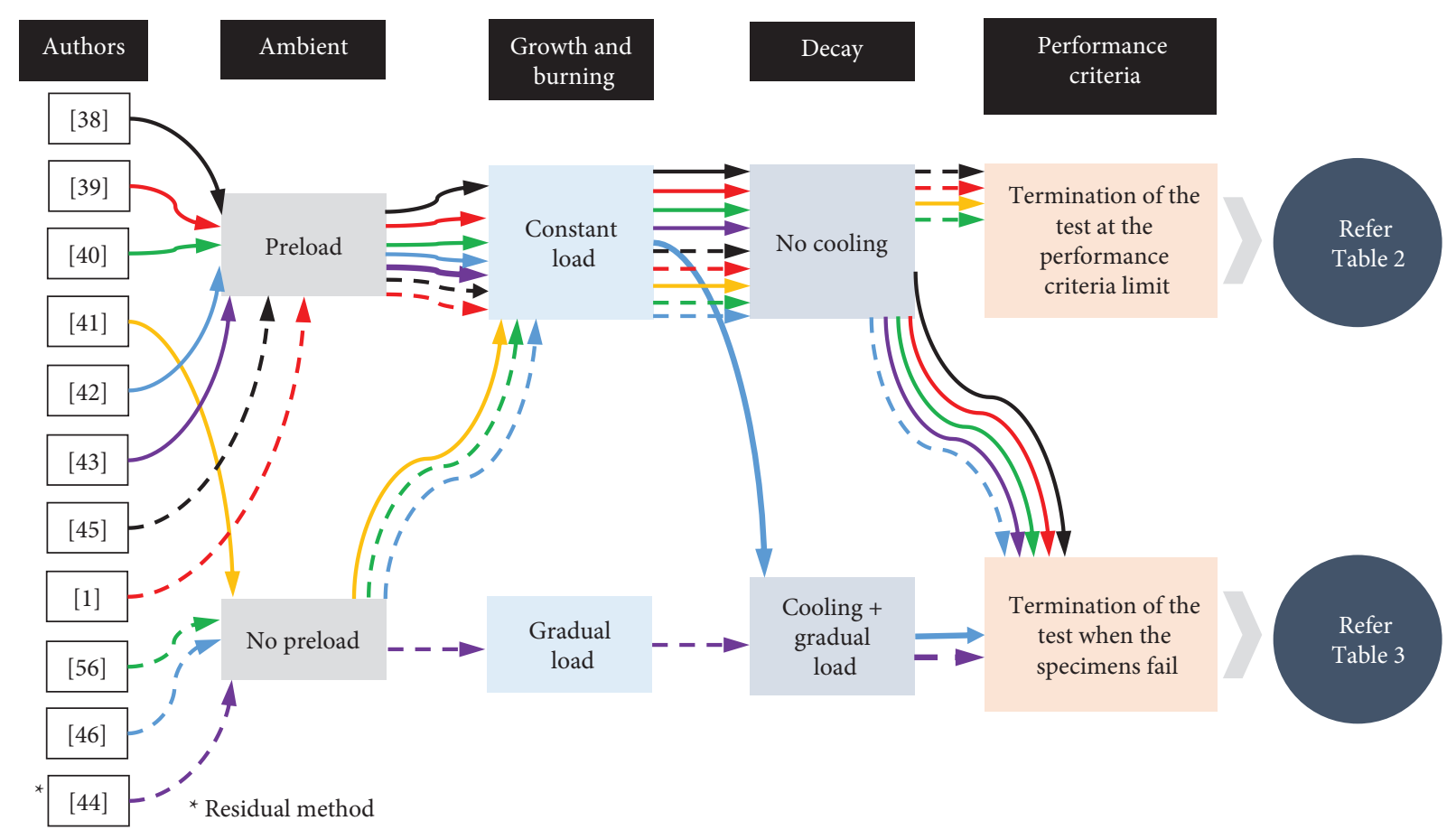

FIGURE 5: The load application and performance criteria for fire tests on beam-to-column connections.

TABle 2: Studies that terminated the fire tests at performance criteria limit.

\begin{tabular}{|c|c|c|c|c|}
\hline $\begin{array}{l}\text { Author, year, } \\
\text { and ref. no. }\end{array}$ & Objectives & $\begin{array}{c}\text { Beam } \\
\text { span/length } \\
(\mathrm{mm})\end{array}$ & Load applications & Performance criteria \\
\hline $\begin{array}{l}\text { Wang et al. } \\
\text { (2011) [41] }\end{array}$ & $\begin{array}{c}\text { Investigate the relative behaviour } \\
\text { and robustness of different types } \\
\text { of steel connection in steel-framed } \\
\text { structures in fire }\end{array}$ & 1980 & $\begin{array}{l}\text { A constant load } 40 \mathrm{kN} \text { was } \\
\text { applied to the steel in each } \\
\text { hydraulic loading Jack, which } \\
\text { corresponds to a load ratio of } 0.5 \\
\text { in the beam }\end{array}$ & $\begin{array}{l}\text { Specimens sustained the applied } \\
\text { load during fire classification } \\
\text { period. The test beams were able } \\
\text { to experience very large } \\
\text { deflections (span/8 span/6) } \\
\text { without fracture }\end{array}$ \\
\hline $\begin{array}{l}\text { Heiza et al. } \\
(2016)[44]\end{array}$ & $\begin{array}{l}\text { Investigate the structural } \\
\text { behaviour and strength reduction } \\
\text { of RC beam-to-column } \\
\text { connections exposed to fire under } \\
\text { cyclic loading }\end{array}$ & 1050 & $\begin{array}{l}\text { Preloaded with } 15 \text { cycle of load } \\
\text { (less than initial crack load) fire } \\
\text { tests under loading equal to } \\
\text { initial crack load for } 1 \text { or } 2 \text { hours }\end{array}$ & $\begin{array}{c}\text { Specimens sustained the applied } \\
\text { load during fire classification } \\
\text { period with concrete spalling and } \\
\text { cracking }\end{array}$ \\
\hline $\begin{array}{l}\text { Raouffard and } \\
\text { Nishiyama } \\
(2017)[1]\end{array}$ & $\begin{array}{l}\text { Investigate the mechanical and } \\
\text { thermal interactions structural } \\
\text { response of RC beam-to-column } \\
\text { subassemblies under no lateral } \\
\text { thermally induced thrust and no } \\
\text { moment redistribution influence }\end{array}$ & 1000 & $\begin{array}{c}\text { Preloaded until first crack } \\
\text { vertical load }(17.3 \mathrm{kN}) \text { constant }\end{array}$ & $\begin{array}{l}\text { The fire tests terminated after } \\
74 \text { min as soon as the tensile } \\
\text { longitudinal steel bars of the } \\
\text { upward-loaded cantilever beam } \\
\text { attained the predefined critical } \\
\text { temperature } 530^{\circ} \mathrm{C}\end{array}$ \\
\hline $\begin{array}{l}\text { Yang and Fu } \\
(2019)[45]\end{array}$ & $\begin{array}{l}\text { Investigate the experimental and } \\
\text { numerical simulation of steel } \\
\text { beam to CFST column composite } \\
\text { connections with RC slabs }\end{array}$ & 2650 & $\begin{array}{c}\text { Load ratio }(0.1 \text { to } 0.35) \text { and } \\
\text { constant }\end{array}$ & $\begin{array}{l}\text { The tests ceased when the } \\
\text { connection specimens achieved } \\
\text { fire resistance when the } \\
\text { deformation or deformation rate } \\
\text { of the square CFST column or } \\
\text { steel beam meet the ultimate } \\
\text { conditions specified in the ISO } \\
\text { 834. The failure patterns of the } \\
\text { connection include tube } \\
\text { buckling, flange buckling, and } \\
\text { separation }\end{array}$ \\
\hline
\end{tabular}


TABLE 3: Studies that terminated the fire tests when the specimens failed.

\begin{tabular}{|c|c|c|c|c|}
\hline $\begin{array}{l}\text { Author, year, } \\
\text { and ref. no. }\end{array}$ & Objectives & $\begin{array}{c}\text { Beam span/length } \\
(\mathrm{mm})\end{array}$ & Load applications & Performance criteria \\
\hline $\begin{array}{l}\text { Ding and } \\
\text { Wang (2007) } \\
{[38]}\end{array}$ & $\begin{array}{l}\text { Present the experimental results of } \\
\text { structural fire behaviour of CFT } \\
\text { column, including failure modes, } \\
\text { development of forces, and } \\
\text { deflections in the beams }\end{array}$ & 2000 & $\begin{array}{l}\text { Preloaded with nominal } \\
\text { load ratio }(0.25 \text { to } 0.5 \text { or } \\
30 \text { to } 60 \mathrm{kN}) \text { and } \\
\text { constant }\end{array}$ & $\begin{array}{l}\text { The heating continued until } \\
\text { structural failure and termination of } \\
\text { the tests; the heating stopped when } \\
\text { the beam reach catenary action and } \\
\text { forced cooling to the ambient } \\
\text { temperature }\end{array}$ \\
\hline $\begin{array}{l}\text { Han et al. } \\
(2010) \text { [39] }\end{array}$ & $\begin{array}{l}\text { Presented the behaviour of RC beam } \\
\text { to CFST column planar frames, } \\
\text { including the deformations and } \\
\text { failures of the test specimens }\end{array}$ & 2325 & $\begin{array}{l}\text { Preloaded (19.5 to } \\
39 \mathrm{kN}) \text { and constant }\end{array}$ & $\begin{array}{l}\text { The fire tests were stopped } \\
\text { immediately when the tested } \\
\text { specimens could not withstand the } \\
\text { loads applied on the CFST columns } \\
\text { and RC beam }\end{array}$ \\
\hline $\begin{array}{l}\text { Ding and } \\
\text { Wang (2009) } \\
{[40]}\end{array}$ & $\begin{array}{c}\text { Investigate structural behaviour } \\
\text { under cooling phase }\end{array}$ & 2000 & $\begin{array}{l}\text { Fire exposure for self- } \\
\text { weight load for } 30 \mathrm{~min}\end{array}$ & $\begin{array}{l}\text { The heating and loading continue } \\
\text { until the connection fail; } \\
\text { the test assemblies were heated to } \\
\text { temperatures close to the failure } \\
\text { temperatures and then cooled down } \\
\text { while still maintaining the applied } \\
\text { loads on the beams }\end{array}$ \\
\hline $\begin{array}{l}\text { Song et al. } \\
\text { (2015) [42] }\end{array}$ & $\begin{array}{c}\text { Present the test results on the } \\
\text { mechanical behaviour of SRC joints } \\
\text { during the heating and cooling } \\
\text { phases }\end{array}$ & 3700 & $\begin{array}{l}\text { Preloaded and constant } \\
\text { during heating and } \\
\text { cooling phase }\end{array}$ & $\begin{array}{l}\text { In postfire loading phase, the } \\
\text { column load was kept constant, and } \\
\text { the beam loads increased gradually } \\
\text { until the connection failure }\end{array}$ \\
\hline $\begin{array}{l}\text { Yahyai and } \\
\text { Rezaeian } \\
\text { (2016) [43] }\end{array}$ & $\begin{array}{l}\text { Investigate the behaviour of beam } \\
\text { and splice connections in column- } \\
\text { tree MRF at elevated temperatures } \\
\text { Study the performance of the three }\end{array}$ & 3980 & $\begin{array}{c}\text { Preloaded (load ratio } \\
0.7 \text { or } 20.6 \mathrm{kN} \text { ) and } \\
\text { constant }\end{array}$ & $\begin{array}{l}\text { The heating and loading continue } \\
\text { until the connection fail }\end{array}$ \\
\hline $\begin{array}{l}\text { Teja et al. } \\
\text { (2019) [46] }\end{array}$ & $\begin{array}{l}\text { different beam column connections } \\
\text { in precast structures exposed to fire } \\
\text { and axial load }\end{array}$ & 670 & $\begin{array}{l}\text { Vertical load (7 to } \\
17 \mathrm{kN}) \text { constant }\end{array}$ & $\begin{array}{c}\text { The heating and loading continues } \\
\text { until specimens fail }\end{array}$ \\
\hline
\end{tabular}

gradual load to the specimens and terminating the test after specimen failure. The residual method simulates the typical idealised column removal scenarios (with and without the cooling effect). The specimens were exposed to fire and then subjected to gradual loading until failure [44].

Table 2 lists the studies that terminated the fire tests at the performance criteria limit. Wang et al. [41] investigated the relative behaviour and robustness of different steel connections in steel-framed structures exposed to fire. They applied a constant load of $40 \mathrm{kN}$ to the steel specimens in each hydraulic loading Jack, corresponding to a load ratio of 0.5 in the beam. The steel connection specimens sustained the applied load during the fire classification period without experiencing a fracture. Heiza et al. [45] studied the structural behaviour and strength reduction of RC beam-tocolumn connections exposed to fire under cyclic loading. They preloaded the concrete specimens with 15 load cycles (less than the initial crack load) before conducting the fire tests at a constant load equal to the initial crack load. The specimens sustained the applied load during the fire classification period and showed concrete spalling and cracking. Raouffard and Nishiyama [1] investigated the mechanical and thermal interactions structural response of RC beam-tocolumn subassemblies under no lateral thermally induced thrust and no moment redistribution influence. They preloaded the concrete specimens until the first crack load before applying a constant vertical load $(17.3 \mathrm{kN})$. The fire tests were terminated after 74 minutes as soon as the tensile longitudinal steel bars of the upward-loaded cantilever beam achieved the predefined critical temperature of $530^{\circ} \mathrm{C}$. Yang and $\mathrm{Fu}$ [56] performed the experimental and numerical simulation of steel beam to CFST column composite connections with RC slabs by applying a constant load ratio of 0.1 to 0.35 to the composite specimens. They terminated the tests when the connection specimens achieved fire resistance (deformation and deformation rate).

Table 3 lists the studies that terminated the fire tests when the specimens failed. Ding and Wang [38] investigated the structural fire behaviour of concrete-filled tubular (CFT) columns, including the failure modes, force development, and beam deflections. They applied a constant load ratio $(0.25$ to 0.5 or 30 to $60 \mathrm{kN})$ to the beam and exposed the structural assembly to the standard fire condition in a furnace while maintaining the applied loads. They continued the heating until the structure failed. Han et al. [39] investigated the behaviour of RC beam to CFST column planar frames, including the deformations and failures of the test specimens. They preloaded the composite specimens to eliminate possible equipment malfunction before applying a constant load of between 19.5 and $39 \mathrm{kN}$. They immediately terminated the fire tests when the CFST columns and RC beam could not withstand the applied loads. Ding and Wang [40] investigated the structural behaviour in the cooling phase. They tested right of the ten test specimens to failure 
during heating; in the other two tests, the test assemblies were heated to temperatures close to the failure temperatures of the axially unrestrained steel beams and then cooled while still maintaining the applied loads on the beams. Song et al. [42] investigated the mechanical behaviour of steel-reinforced concrete (SRC) joints during the heating and cooling phases. They preloaded the composite specimens using three jacks before conducting the fire tests under a constant load. In the postfire loading phase, the column load was kept constant, and the beam loads were increased gradually until the connection failed. Yahyai and Rezaeian [43] investigated the behaviour of beam and splice connections in columntree moment resisting frames (MRF) at elevated temperatures. They preloaded the steel specimens with a constant load ratio of 0.7 or $20.6 \mathrm{kN}$ and applied the heating and loading until the connection failed. Teja et al. [46] studied the thermal performance of three different beam-to-column connections in precast structures subjected to a constant load $(7$ to $17 \mathrm{kN})$ during heating until the connections failed.

Figure 5 shows the load applications after the fire tests (residual method), where Li et al. [44] simulated the typical idealised column removal scenario under fire. In this study, the RC beam-to-column connection specimens with varying reinforcement development lengths were exposed to fire, with and without cooling effects, and then subjected to pushdown loads. A vertical load of 20 to $90 \mathrm{kN}$ was applied until the bottom reinforcements fractured or pulled out.

Table 2 shows that Heiza et al. [45] and Raouffard and Nishiyama [1] did not apply the superimposed and service load required by ASTM E119 and ISO 834. Instead, they used the first crack load, $P_{f}$, as a reference value for the load. Mindess et al. [57] and Hamad and Sldozian [58] defined the first crack load as the point on the load-deflection curve at which the curve first become nonlinear. The first crack strength represents the RC behaviour to the inception and beginning of a crack in the matrix. There are two methods for determining the first crack value. The first method is visual observation during the load test. However, concrete contains microcracks that grow as soon as the concrete is loaded. Thus, it is hard to achieve the first crack deflection because it is minor due to various extraneous deflections that may occur due to machine deformations and placing them on the supports. The second method is calculating the first crack deflections, $\delta$ [57] using the following formula:

$$
\delta=\frac{23 P l^{3} / 1296 E I}{\text { flexural component }} \times \frac{\left[1+216 d^{2}(a+\mu) / 115 l^{3}\right]}{\text { shear component }},
$$

where $d$ is the midspan deflection, $P$ is the load at first crack, $l$ is the span length, $E$ is the modulus of elasticity, $\mu$ is Poisson's ration, $I$ is the moment of inertia, and $d$ is the beam depth.

2.7. Conclusion on the Fire Testing of Beam-to-Column Connections. The following conclusions are drawn based on the discussion in Sections 2.1-2.6. In buildings with large, open compartments, the fire tends to travel horizontally and vertically as the flames spread by igniting the fuel in their path and burning it in a limited area at any one time. The localised horizontal and vertical travelling fires induce the temperature development of the beam-to-column connections through two temperature fields, the near and far fields. Researchers considered several factors to address the lack of structural fire performance testing methods for the beam-tocolumn connections. Based on the test objective and performance criteria adopted in previous studies, this review paper has summarised seven fire testing criteria. Of these, there is significant inconsistencies in Criteria 7 (loading applications), where the load was applied either in the preloading (structural response at ambient conditions), concurrent (thermomechanical response during fire exposure), or postfire (residual response after cooling down) phase, or a combination these phases. The loads were applied to the specimens constantly or gradually. The fire tests were terminated at the performance criteria limit when investigating the thermal behaviour, thermal interaction, and strength reduction. When determining the failure load and maximum deformation (deflection, expansion or contraction), the fire tests were terminated at specimens' failure. Besides the superimposed and service load stated in ASTM E119 and ISO 834, the researchers also employed the first crack load as the reference value for the load.

\section{Issues and Challenges}

3.1. Selection of the Structural Assembly. The literature shows that researchers faced a conflict when selecting a fire test method, whether standard fire testing or nonstandard structural fire testing. Regardless of the fire test method, the beam-to-column connection structural assembly must represent the actual structural behaviour [10]. Several factors are taken into account before assembling the specimens. Figure 6 demonstrates the relationship performance of the fire test based on different structural assemblies and fire curves.

The specimens for the beam-to-column connections can be assembled as a partial element, single element, subframe assembly, restrained assembly, or full-scale structure [53]. According to the ASTM E119 and ISO 834 guidelines, the specimens can only be assembled as a partial element and single element (vertical and horizontal building elements) subject to the standard time-temperature fire curves conditions, as shown in Figure 6. The fire testing of beam-to-column connections in previous research did not follow ASTM E119 and ISO 834 guidelines. The specimens were assembled as subframe assemblies subjected to elevated temperature (steady-state and transient) [46] and restraint assemblies subjected to standard time-temperature fire curves $[1,38,43,45,56]$. According to Gales et al. [53], the objective of the large-scale nonstandard structural fire tests that employed the full-scale structures and real fire curves is to understand the real structural performance of buildings subjected to construction and real fires. It is not possible to achieve this understanding through the standard fire testing furnace.

Based on Figure 6, it is apparent that a more complex structural assembly gives more accurate test results. The fullscale structures with complex structural assembly represent the building's actual structural behaviour. However, setting 


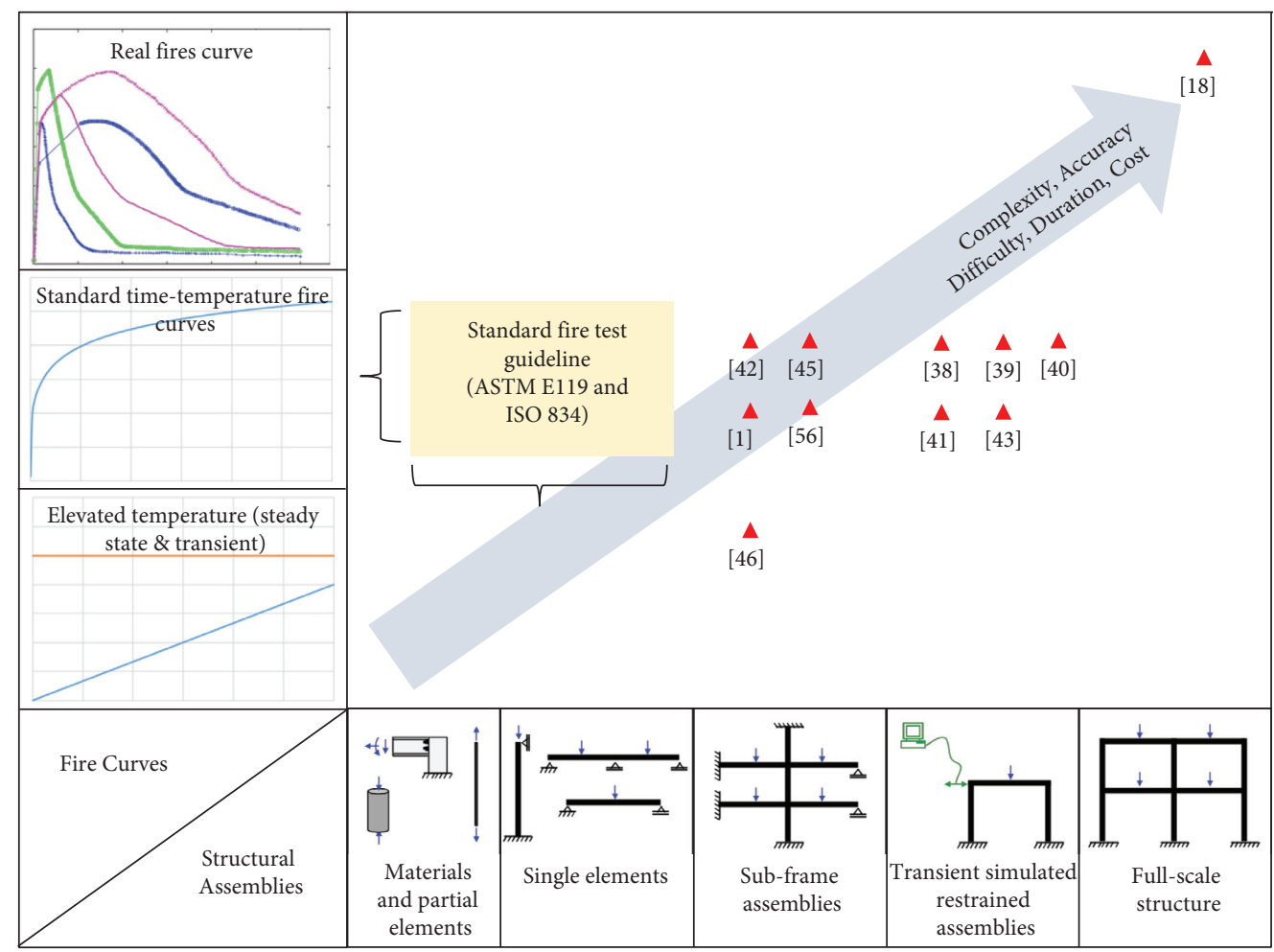

Figure 6: The relationship performance of fire tests based on different fire curves and structural assemblies.

up a complex structural assembly, including the specimen and testing procedures, are complicated and time-consuming. For example, the Cardington full-scale building fire tests in the United Kingdom for an eight-storey office building specimens involved six fire tests on the composite frame, namely, the restrained beam test, plane frame test, first corner test, second corner test, large compartment test, and demonstration test [59]. In addition, a nonstandard structural fire test is expensive and requires a real fire in actual scale framed buildings. The test also requires sufficient instrumentation to understand the fire and the structural response. Because of the high cost of physical fire tests, the finite element methods based on well-validated models are viable alternatives.

\subsection{Real Fire Time-Temperature Curves vs. Standard Time-} Temperature Fire Curves. In recent years, researchers and regulators have dealt with the use of standard time-temperature fire curves in simplified single element tests and isolated structural members subjected to unrealistic temperature-time curves $[15,16,60,61]$. The standard timetemperature fire curves have little resemblance to the real fire temperature-time history. They do not have a decay phase and represent any real fire. They were designed to typify the temperatures experienced during the post-flashover phase of most fires [53]. The mock-up assembly's fire-resistance rating (hours) cannot represent the actual construction and real fire. It only tests the survival components of the fire exposure and can be compared as a relative index system to the design. As a result, nonstandard structural fire testings that employed real fire curves are a more rational approach that might present the full suite of interactions expected in actual building fires.

Even though the standard time-temperature fire curves do not have a decay stage at the end and appear more severe than a real fire, they are suitable for all three phases (growth, burning, and decay) of the fire tests. ISO 834 specifies that, even after termination, the fire tests can be continued after they have achieved the selected performance criteria to gather additional data, including the data on failure patterns and ultimate failure load. ASTM E119 evaluates the ability of the assemblies to remain intact in the decay phase by applying a specified standard fire hose stream to the structure.

Kodur and Agrawal [62] presented the postfire residual response of structural elements after cooling. Figure 7 shows that the heating scenario was subjected to the fire classification period $(1,1.5$, and 2 hours) specified in ISO 834 . The fire classification period is the performance resistance to the standard exposure elapsing before observing the first critical point in behaviour is observed. The fire classification period does not refer to the survival times or any explicit attempt to quantify the structural damage of the real structure in a real fire but to the expected fire resistance period for the structural components subjected to a standard temperaturetime curve in standard furnace fire tests [2]. The decay stage is simulated through a linear decrease in air temperature following the fire exposure.

3.3. Structural Response of the RC Beam-to-Column Connections in the Cooling Phase. Many studies have been conducted on the cooling phase of steel and composite beam-to-column connections, but there is a dearth of study 


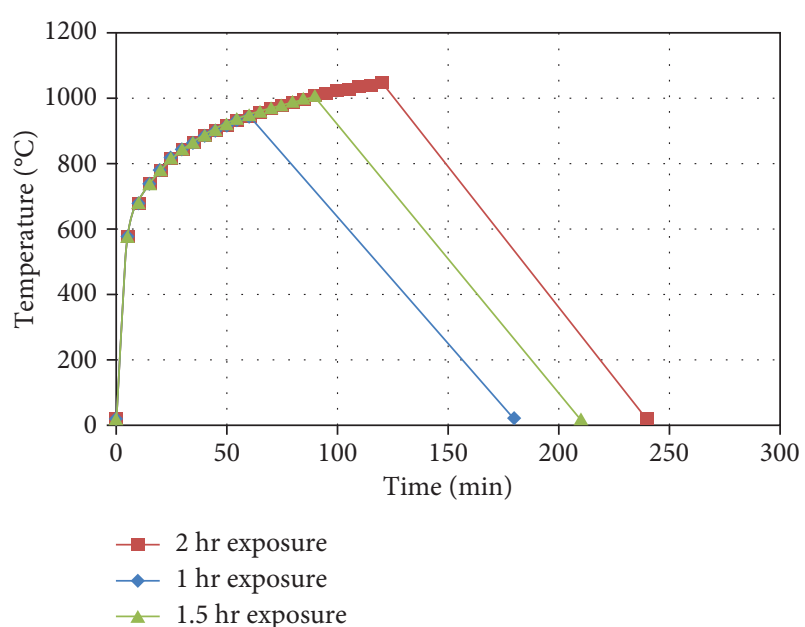

FIgURE 7: Fire exposure using the ISO 834 fire curve with a decay phase [62].

on the structural response of RC beam-to-column connections in the cooling phase. There is a significant difference in the thermal properties of concrete and steel materials. The thermal conductivity of steel (between 27 and $53 \mathrm{~W} / \mathrm{mK}$ ) is higher than concrete (between 0.5 and $1.3 \mathrm{~W} /$ $\mathrm{mK})[63,64]$. This significant difference enhances the ability of a material to transfer heat in the cooling phase of connections. The literature shows that the temperature of the CFST column and steel beam in the joint zone is lower than those in the nonjoint zones during the heating phase but higher during the cooling phase [65]. Besides the thermal properties, the SRC column and beam showed significant deformation in the cooling phase than the heating phase, leading to the potential failure of SRC joints in the cooling phase $[42,66]$. The relative increase in the beam-to-column rotation angle in the cooling phase is approximately 1.5 times higher than the increase in the heating phase. The duration of the heating phase that causes failure of the composite column during or after the cooling phase is always shorter than the fire resistance of structures exposed only to heating [67].

Heiza et al. [45] investigated the structural response of RC beam-to-column connections during the cooling phase. Their study focused on the structural behaviour and strength reduction of RC beam-to-column connections exposed to fire under cyclic loading. They removed the front part of the furnace at the end of the heating phase and begun the loading cycles while recording the deflection, strain, and cracks at each load increment until they reached the failure load. However, they did not explain the cooling phase effect and comparison of the heating and cooling phases.

Kodur and Agrawal [62] studied the structural response of RC structure in the cooling phase and found that the single RC beam element retained 60 to $70 \%$ of the ultimate room temperature capacity for a range of parametric fire exposure scenarios with a distinct cooling phase. Dwaikat and Kodur [68] found that the cooling phase reduces the fire-induced spalling in concrete. They observed that the pore pressure decreased with fire exposure because of the lower temperature and did not anticipate further concrete spalling. Gernay [69] addressed that the fire safety analysis of RC structure should consider until the complete burnout of a fire, cooling phase, and beyond to assess the safety during fire brigades intervention, building inspection, and possibly building rehabilitation.

3.4. Test Load Value. There are three issues when applying the test load on the beams. First, not all fire tests are conducted with preloading under ambient conditions, as shown in Figure 5. ASTM E119 stated that the test specimens should truly represent the construction, for which classification is desired, as to materials, workmanship, and details, such as dimensions of parts. The test specimens should be constructed under conditions representative of building construction and operation. The absence of preload before the fire tests will not provide an initial load to the beam, equal to the initial crack load or based on load ratio, and eliminate possible equipment malfunction. In real building conditions, the fire starts when a service load is applied to the structure.

Second, because the test load applied to the beam is lower than the required value, the test could not simulate the maximum superimposed and service load condition throughout the fire tests. The test load value is dependent on several factors, including the beam span. A short beam span produces a lower test load value. Given the current standard fire testing methods, the standards specify that the beam span exposed to the fire should not be less than $3.7 \mathrm{~m}$ (ASTM E119) and $4.0 \mathrm{~m}$ (ISO 834). However, Tables 2 and 3 show that the beam span for the specimens with the simply supported setup is between $1980 \mathrm{~mm}$ and $3980 \mathrm{~mm}$, and the length of the cantilever beam is between $670 \mathrm{~mm}$ and $1050 \mathrm{~mm}$. Assuming a cantilever beam is half the actual beam span (subassembly's concept), the beam length is between $1340 \mathrm{~mm}$ and $2100 \mathrm{~mm}$. The beam span of specimens is less than the length required in the standards, and the shorter beam span provides a lower superimposed load or service load than the required load, and the beam will not react accordingly to the lower applied load.

Finally, another significant issue is the application of the first crack load as the reference test load. The theoretical first crack load is low compared with the observed experimental first crack loads. Kankam and Odum-Ewuakye [70] investigated the flexural strength and deformation of two-way RC slabs and found that the experimental failure loads are approximately $170 \%$ of the predicted values. Audu and Oseni [71] investigated the cracks and crack patterns on RC slabs and found that the difference between the experimental first crack load and the theoretical first crack load is between $14.2 \%$ and $59.7 \%$. As the load increases, the crack formation is followed by multiplication and further cracking. The complete development of yield lines gave a lower theoretical yield load than the experimental values. This behaviour could be due to the adopted safety factor in the design.

3.5. Constraints in the Data Collection. The beam-to-column connections elements are exposed to high temperatures in the furnace, making it difficult to determine some of the 
required study parameters. It is essential to address several factors when comparing the test result from the ambient temperature with the high temperature. In some cases, the instruments have to be protected with fire-resistive material to prevent damage.

Researchers could not record the crack development and failure mode during the heating and loading of the RC specimens and only obtain the result after the furnace cooled down. Similarly, the failures of steel connections, such as buckling, shear fracture of the bolt, and bearing deformation of the bolt holes, are only visible after the fire test. This situation is different from the normal load test, where researchers can monitor the outcomes of load applications. The strain gauge used at ambient temperature is very sensitive to high temperatures. Researchers need to use temperature resistive strain gauges for the reinforcing bars, steel structure, and concrete structure. However, the strain gauges did not perform well at high temperatures and failed to capture significant data [1].

The inclinometer for measuring the inclination and rotation of the beam cannot be used in a fire test. Figure 8 shows the inclinometer being used at ambient temperature [73]. Nonetheless, researchers can use the results from the linear variable differential transformer (LVDT) from the column and beam to calculate the rotation (milirad) [73]. The calculation is given by

$$
\theta=\left\{\left[\tan ^{-1} \frac{b}{d}\right]-\left[\tan ^{-1} \frac{a}{c}\right]\right\} \frac{100 \pi}{18},
$$

where $a$ is the displacement at column; $b$ is the displacement at beam; $c$ is the distance from LVDT to centre of rotation for column; $d$ is the distance from LVDT to centre of rotation for beam.

The structural deformation during the fire test influences the consistency of the constant load applied to the beam. Whether the load is applied hydraulically, mechanically or by weights, there will be changes in the dimension or shape of an element of construction due to structural and thermal actions as the load increase. These changes include deflection, expansion, and contraction of the structural elements. It is difficult to control and monitor the loading consistency throughout the fire duration. The application of permanent load blocks to the designated position of the specimens $[1,43]$ requires a bigger space and more supporting equipment. The limited space makes it hard to install the load blocks and protect them with a ceramic fibre blanket in the furnace, as shown in Figure 9. Some electric furnaces are not designed for the load-bearing function. The rapid deflection of the beams during the fire test could bring down the loading blocks and damage the furnace [1]. In addition, the large load blocks and narrow space could prevent the heating in the furnace from achieving the required timetemperature fire curves.

3.6. Boundary Conditions for the Column. The restrained lateral movement and fixed end at the top and bottom column support in previous studies did not simulate the actual bending moment diagram of the column structure. By

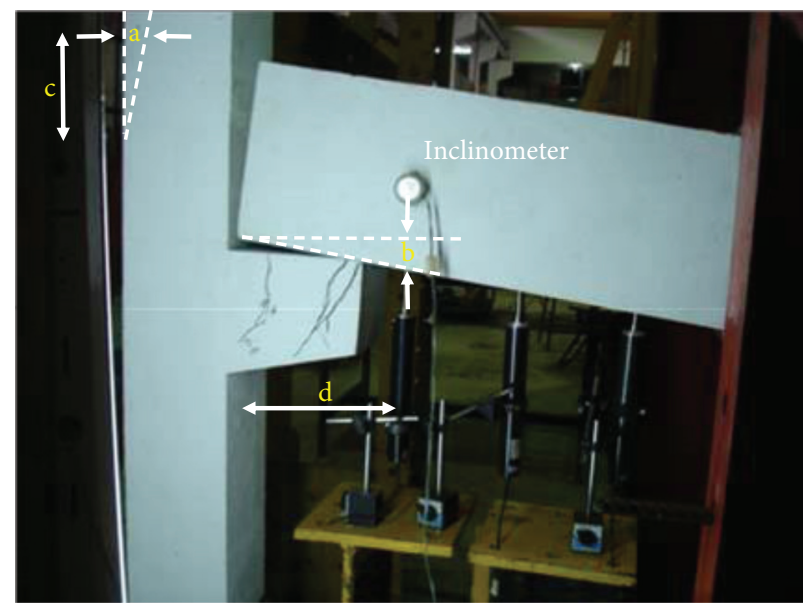

FIGURE 8: The installed inclinometer and measurement of the displacement of the beam and column [73].

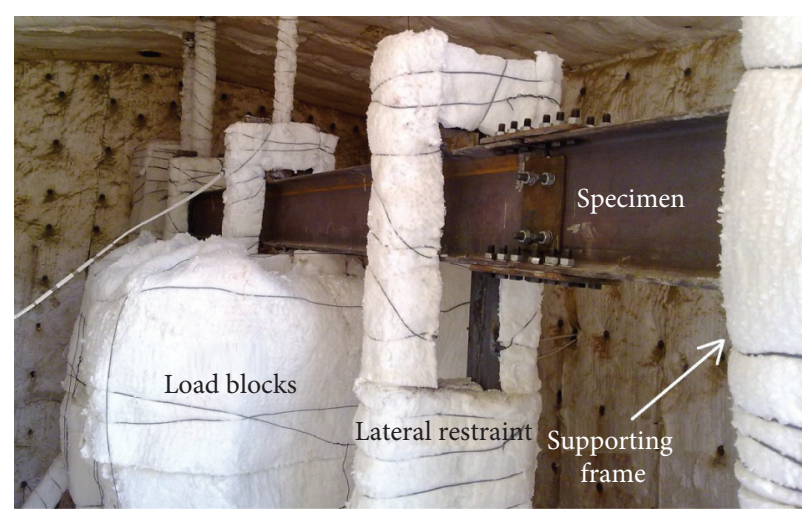

Figure 9: The load blocks in fire tests [43].

considering the length of the column is half from the actual storey of the building, the representative and definable manner bending moment diagram of the column will be shown as Figure 10. On this basis, the top and bottom of column support located at A and B (centre of column) will behave as a pin with zero moments. At the connection, there will be a significant value of moment for the column.

However, a different reaction was observed when applying the restrained lateral movement and fixed end conditions, and there will a significant value of bending moment diagram at column support located at $\mathrm{A}$ and $\mathrm{B}$. The columns were restrained from lateral movement (to provide axial restraint to the beam) at the ends and were free to move in the longitudinal direction [38].

3.7. Fire Intensity at the Connections. The estimation of the maximum temperature in building fires is made at the location of the local fuel and flaming region. Considering a similar fire development with horizontal and vertical travelling fires shown in Figure 2, the maximum temperature is at the midspan of the beam instead of the connection region. However, the literature review revealed that previous fire testing provided direct heating to the connection, which did not accurately simulate the intensity of a real fire. After 


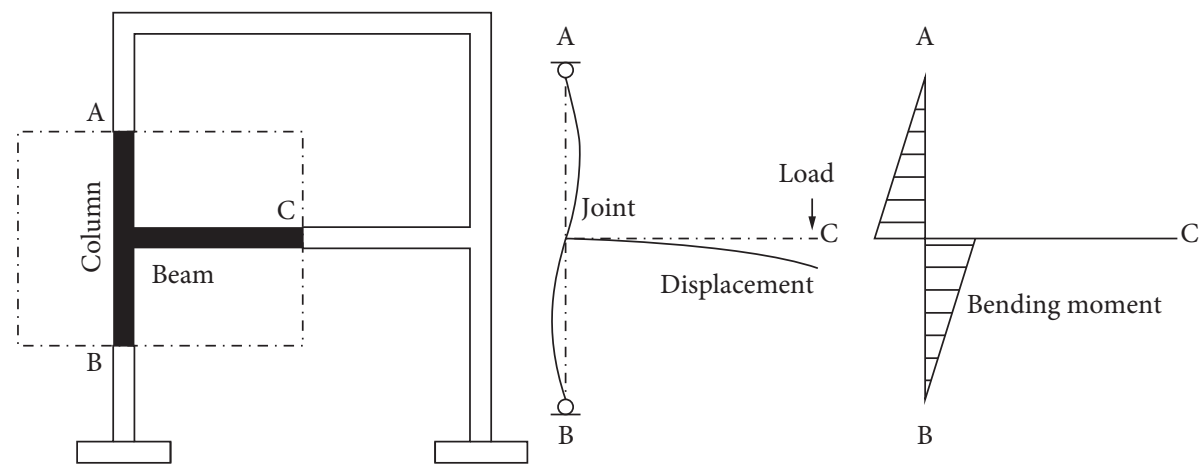

FIGURE 10: Bending moment diagram for the column member.

ignition occurs in a building, the fire spreads upward to the top structural member because the flame spreads on the burning object before moving to the adjacent connections [36]. The fire plume provides a buoyant convective transport of the combustion products up to the ceiling. The critical factor influencing the flame spread is the heating rate of the fire sources ahead of the flame. The thickness and temperature of the hot layer increase as the fire grows. According to Merci and Van Maele [72], the total heat release rate determines the average temperature rise of the hot smoke layer. However, the fire source area and roof opening have less influence on the average temperature rise.

Wroblewski et al. [74] described real fire incidents involving the concept of fire spread. The centre of the RC girders exhibited significant fire damage and pushed-out joining parts; the posttensioned roof girders, RC slabs, and columns sustained considerable damage, as shown in Figure 11. These thermal reactions reduced the moment capacity, rotational capacity, and rotational stiffness of the beam-to-column connections. Han et al. [39] found that the connection zone of the frame has a significantly lower temperature than the beam and column sections. The connection zone behaved as a rigid connection and did not show signs of failure in the fire tests.

3.8. Conclusion of the Issues and Challenges. The following conclusions are drawn based on the discussions in Sections 3.1-3.7. The selected beam-to-column connection structural assembly must represent the actual structural behaviour. A more complex structural assembly will produce a more accurate result even though the fire test is more timeconsuming and expensive and involves complicated procedures. Even though the standard time-temperature fire curves do not have a decay phase at the end and appear more severe than the real fire, they are suitable for conducting fire tests for the growth, burning, and decay phases. There are many studies on the cooling phase of steel and composite beam-to-column connections, but there is a dearth of studies on the structural response of the $\mathrm{RC}$ beam-to-column connections in the cooling phase. The literature review revealed that there are three issues with the test load applied to the beam. (1) Not all fire tests are conducted with preloading at ambient conditions, (2) the test load applied to the beam is lower than the required load, and (3) the theoretical

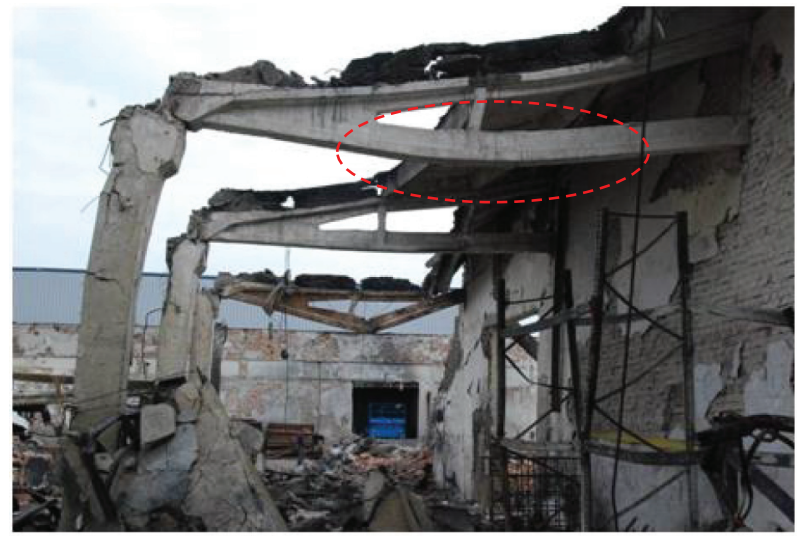

FIGURE 11: Deformation of the centre of the RC girders in a real fire incident [74].

first crack load is lower than the observed experimental first crack loads. There is also difficulty in determining some of the required study parameters because the beam-to-column connections elements are in the furnace and exposed to high temperatures. The restrained lateral movement and fixed end conditions at the top and bottom of the column support in previous studies did not simulate the actual bending moment diagram of the column structure. The maximum temperature in building fires is estimated at the flaming region, depending on the location of the local fuel. The literature review revealed that previous fire testings provided direct heating to the connection, which did not accurately simulate the intensity of a real fire.

\section{Recommendations and the Way Forward}

There is a need for researchers and regulators to provide a standard method for determining the fire resistance of beam-to-connection connections exposed to fire. This need arises due to the increasing conflicts in the current fire testing methods and disagreement on the standard fire tests adopted in simplified single element tests and isolated structural members subjected to unrealistic temperaturetime curves. The fire tests of the beam-to-connection connection elements may consider all phases of the fire, including the growth, flashover, fully developed, and decay or cooling phases, to obtain a complete result. In some cases, 
the buildings collapse in the decay phase of the fire. The concept of equivalent fire severity relates the severity of an expected real fire to the standard fire tests. This concept is essential when comparing published fire-resistance ratings from standard tests with the severity estimates of a real fire.

The test load applied to the beam has to simulate the maximum load condition in the fire tests. The maximum load condition is a superimposed load, service load, actual material properties, characteristic material properties, or the first crack load representing the worst-case structure scenario. The testing laboratory should indicate the basis for determining the test load and the condition allowed under each nationally recognised structural design criteria. The maximum load condition will facilitate the primary goal of load testing to demonstrate the safety of a structure against failure.

The structural fire safety design must consider the severe condition of the midspan and structural member's connection during the fire. Even though the fire spread concept states that the maximum temperature is often recorded at the midspan of the member instead of the connection, the literature review showed that the connection elements of any building structure are critical and vulnerable during the heating and cooling phases of the building fire. The momentrotation-temperature characteristics of the connections at elevated temperatures are influenced by the fire effects on the RC structure, including deflection, cracking, spalling, loss of stiffness, and strength and loss of reinforcement strength.

Finally, the adoption of performance-based structural fire design (PBSFD) in beam-to-column connections could explicitly define the levels of structural fire safety performance and produce more efficient and economical building designs $[75,76]$. PBSFD uses analytical tools and experimental findings to design structures for fire safety. It does not rely on the current prescriptive code of requirements for structural fire protection, known as standard fire resistance design (SFRD), that does not explicitly evaluate structural fire performance. It is essential to understand and quantify the behaviour of the connections for a range of fire scenarios to ensure a resilient structure for extreme fire events.

\section{Conclusions}

This paper has reviewed the structural fire performance testing methods of beam-to-column connections of the fire testings conducted from 2007 to the present. The structural fire performance tests of beam-to-column connections provided significant results on the connections' fire performance and fire resistance. The required fire performances were assessed according to standardised test procedures with strict performance criteria. Based on the literature review, the following conclusions are drawn.

(i) The fire in a building with large, open compartments tends to travel horizontally and vertically as flames spread by igniting and burning the fuel in their path in a limited area at any one time.

(ii) A real fire develops in four phases, growth, flashover, fully developed, and decay or cooling.
However, the standard temperature-time fire curves have little resemblance to the real fire temperature-time history.

(iii) ASTM E119 and ISO 834 provide the method for determining the fire resistance of the construction elements exposed to the standard fire conditions. However, these standards do not provide the methods for verifying the fire behaviour of the connections between building elements. They focus on separate vertical and horizontal building elements.

(iv) Despite the lack of fire performance test guidelines for the beam-to-column connections, researchers have conducted numerous fire tests on rigid, semirigid, and pinned beam-to-column connections.

(v) The seven fire testing criteria for the beam-tocolumn connections summarised from previous studies are the materials, type of connections, method of connections, boundary conditions (constraints), fire sources, type of analysis, and load applications.

(vi) There are significant inconsistencies in the loading applications (Criteria 7), where the load is applied in the preloading, concurrent, and postfire phases, or a combination of these phases.

(vii) The issues and challenges faced by researchers are the selection of structural assembly, arguments of real fire time-temperature curves against standard time-temperature fire curves, structural response of the RC beam-to-column connections in the cooling phase, test load value, constraints in data collection, boundary conditions of the column, and fire intensity at the connections.

(viii) There is a need for researchers and regulators to provide a standard method for determining the fire resistance of the beam-to-connection connections exposed to fire. The test load applied to the beam has to simulate a maximum load condition during the fire tests. The structural fire safety design should consider the severe conditions of the midspan and structural member's connection during the fire. The adoption of PBSFD in beamto-column connections has explicitly defined the levels of structural fire safety performance and produces more efficient and economical building designs [77].

\section{Data Availability}

No data were used to support this study.

\section{Conflicts of Interest}

The authors declare that they have no known conflicts of financial interests or personal relationships that could have appeared to influence the work reported in this paper. 


\section{Acknowledgments}

The authors acknowledge the financial support from Universiti Kebangsaan Malaysia through Research University Grant (grant no. GUP-2018-027) and laboratory facilities provided by the Department of Civil Engineering, Faculty of Engineering and Built Environment, Universiti Kebangsaan Malaysia.

\section{References}

[1] M. M. Raouffard and M. Nishiyama, "Fire response of exterior reinforced concrete beam-column subassemblages," Fire Safety Journal, vol. 91, pp. 498-505, 2017.

[2] V. Dao, J. Torero, C. Maluk, and L. A. Bisby, "Fire performance of concrete using novel fire testing," Concr. Aust.vol. 42, no. 1, pp. 58-59, 2016.

[3] I. Hollý and I. Harvan, "Connections in precast concrete elements," Key Engineering Materials, vol. 691, pp. 376-387, 2016.

[4] H. H. Ghayeb, H. A. Razak, and N. H. R. Sulong, "Seismic performance of innovative hybrid precast reinforced concrete beam-to-column connections," Engineering Structures, vol. 202, Article ID 109886, 2020.

[5] S. Elsawaf and Y. C. Wang, "Behaviour of restrained structural subassemblies of steel beam to CFT column in fire during cooling stage," Engineering Structures, vol. 46, pp. 471-492, 2013.

[6] J. Beitel and N. Iwankiw, Analysis Of Needs And Existing Capabilities For Full-Scale Fire Resistance Testing, Nist Gcr 02843-1NIST, Gaithersburg, MD, USA, 2008, http://www.bfrl. nist.gov/866/pubs/NISTGCR02-843.pdf.

[7] Building and Construction Authority (Bca), Connections for Advanced Precast Concrete System, Building and Construction Authority (BCA), Singapore, 2018.

[8] R. Mokhtar, Z. Ibrahim, M. Z. Jumaat, Z. A. Hamid, A. H. A. Rahim, and A. Rahim, "Behaviour of semi-rigid precast beam-to-column connection determined using static and reversible load tests," Measurement, vol. 164, Article ID 108007, 2020.

[9] N. A. M. Radzi, R. Hamid, and A. A. Mutalib, "A review of methods, issues and challenges of small-scale fire testing of Tunnel lining concrete," Journal of Applied Sciences, vol. 16, no. 7, pp. 293-301, 2016.

[10] American Society of Testing Materials, ASTM E119-07: Standard Methods of Fire Test of Building Construction and Materials, ASTM International, PA, USA, 2007.

[11] International Organization for Standardization, ISO 834-1, Fire Resistance Test - Elements of Building Construction, Part 1: General Requirements, International Organization for Standardization, Geneva, Switzerland, 1999.

[12] N. A. M. Radzi, R. Hamid, A. A. Mutalib, and A. B. M. Kaish, "A review of precast concrete beam-to-column connections subjected to severe fire conditions," Advances in Civil Engineering, vol. 2020, Article ID 8831120, 23 pages, 2020.

[13] Y. Li and J. Zhao, "Research review on the behavior of steel beam to column endplate connections in fire," Progress in Steel Building Structures, vol. 22, no. 1, 2020.

[14] T. Lennon, Structural Fire Engineering, ICE Publication, London, UK, 2011.

[15] J. Gales, L. A. Bisby, and M. Gillie, "Unbonded post tensioned concrete in fire: a review of data from furnace tests and real fires," Fire Safety Journal, vol. 46, no. 4, pp. 151-163, 2011.
[16] L. Bisby, J. Gales, and C. Maluk, "A contemporary review of large-scale non-standard structural fire testing," Fire Science Reviews, vol. 2, no. 1, p. 1, 2013.

[17] K. H. Almand, NET-SFPE workshop for development of a national R\&D roadmap for structural fire safety design and retrofit of structures: Proceedings, NISTIR 7133, National Institute of Standards and Technology, Gaithersburg, MD, USA, 2004.

[18] A. Law, J. S. Gottfried, M. Gillie, and G. Rein, "The influence of travelling fires on a concrete frame," Engineering Structures, vol. 33, no. 5, pp. 1635-1642, 2011.

[19] X. Dai, S. Welch, and A. Usmani, "A critical review of "travelling fire" scenarios for performance-based structural engineering," Fire Safety Journal, vol. 91, pp. 568-578, 2017.

[20] J. Stern-Gottfried and G. Rein, "Travelling fires for structural design-Part I: literature review," Fire Safety Journal, vol. 54, pp. 74-85, 2012.

[21] E. Rackauskaite, C. Hamel, A. Law, and G. Rein, "Improved formulation of travelling fires and application to concrete and steel structures," Structures, vol. 3, pp. 250-260, 2015.

[22] A. Buchanan, "The challenges of predicting structural performance in fires," Fire Safety Science, vol. 9, pp. 79-90, 2008.

[23] G. C. Clifton, "Fire models for large firecells," HERA, Report R4-83, HERA, Manukau City, 1996.

[24] J. Stern-Gottfried and G. Rein, "Travelling fires for structural design-Part II: design methodology," Fire Safety Journal, vol. 54, pp. 96-112, 2012.

[25] J. S. Gottfried, Travelling Fires for Structural DesignThe University of Edinburgh, King's Buildings campus, Edinburgh, Scotland, 2011.

[26] C. G. Bailey, I. W. Burgess, and R. J. Plank, "Analyses of the effects of cooling and fire spread on steel-framed buildings," Fire Safety Journal, vol. 26, pp. 273-293, 1996.

[27] E. Ellobody and C. G. Bailey, "Structural performance of a post-tensioned concrete floor during horizontally travelling fires," Engineering Structures, vol. 33, no. 6, pp. 1908-1917, 2011.

[28] C. Röben, M. Gillie, and J. Torero, "Structural behaviour during a vertically travelling fire," Journal of Constructional Steel Research, vol. 66, no. 2, pp. 191-197, 2010.

[29] B. Behnam, "On the effect of travelling fire on the stability of seismic-damaged large reinforced concrete structures," International Journal of Civil Engineering, vol. 14, no. 8, pp. 535-545, 2016.

[30] B. Behnam and H. R. Ronagh, "Behavior of moment-resisting tall steel structures exposed to a vertically traveling postearthquake fire," The Structural Design of Tall and Special Buildings, vol. 24, pp. 421-439, 2014.

[31] J. Jiang, Y. Lu, X. Dai, G.-Q. Li, W. Chen, and J. Ye, "Disproportionate collapse of steel-framed gravity buildings under travelling fires," Engineering Structures, vol. 245, Article ID 112799, 2021.

[32] R. L. Alpert, "Calculation of response time of ceiling-mounted fire detectors," Fire Technology, vol. 8, no. 3, pp. 181-195, 1972.

[33] K. L. Friquin, Charring Rates of Heavy Timber Structures for Fire Safety Design A Study of the Charring Rates under Various Fire Exposures and the Influencing Factors, Norwegian University of Science and Technology, Trondheim, Norway, 2010.

[34] T. Gernay and J.-M. Franssen, "The introduction and the influence of semi-rigid connections in framed structures subjected to fire," Fire Safety Journal, vol. 114, Article ID 103007, 2020.

[35] M. F. Green, N. Benichou, V. Kodur, and L. A. Bisby, "Design guidelines for fire resistance of FRP-Strengthened concrete 
structures," in Proceedings of the 8th International Symposium on Fiber Reinforced Polymer Reinforcement for Concrete Structure (FRPRCS-8), pp. 1-10, Patras, Greece, July 2007.

[36] A. H. Buchanan and A. K. Abu, Structural Design for Fire Safety, John Wiley \& Sons, Hoboken, N J, US, 2017.

[37] B. Behnam, "Failure sensitivity analysis of tall momentresisting structures under natural fires," International Journal of Civil Engineering, vol. 16, no. 12, pp. 1771-1780, 2018.

[38] J. Ding and Y. C. Wang, "Experimental study of structural fire behaviour of steel beam to concrete filled tubular column assemblies with different types of joints," Engineering Structures, vol. 29, no. 12, pp. 3485-3502, 2007.

[39] L. H. Han, Y. Q. Zheng, Z. Tao, and W. H. Wang, "Experimental behaviour of reinforced concrete (RC) beam to concrete-filled steel tubular (CFST) column frames subjected to ISO-834 standard fire," Engineering Structures, vol. 32, pp. 3130-3144, 2010.

[40] J. Ding and Y. C. Wang, “Temperatures in unprotected joints between steel beams and concrete-filled tubular columns in fire," Fire Safety Journal, vol. 44, no. 1, pp. 16-32, 2009.

[41] Y. C. Wang, X. H. Dai, and C. G. Bailey, "An experimental study of relative structural fire behaviour and robustness of different types of steel joint in restrained steel frames," Journal of Constructional Steel Research, vol. 67, pp. 1149-1163, 2011.

[42] T. Y. Song, L. H. Han, and Z. Tao, "Structural behavior of SRC beam-to-column joints subjected to simulated fire including cooling phase," Journal of Structural Engineering, vol. 141, no. 9, pp. 1-12, 2015.

[43] M. Yahyai and A. Rezaeian, "Behavior of beams in bolted column-tree frames at elevated temperature," Fire and Materials, vol. 40, no. 3, 2016.

[44] Z. Li, Y. Liu, J. Huo, H. Rong, J. Chen, and A. Y. Elghazouli, "Experimental assessment of fire-exposed RC beam-column connections with varying reinforcement development lengths subjected to column removal," Fire Safety Journal, vol. 99, pp. 38-48, 2018.

[45] K. Heiza, M. Taha, and M. Soliman, "Performance of reinforced concrete beam column connections exposed to fire under cyclic loading," in Proceedings of the 2016 International Conference on Civil, Architecture and Environmental Engineering (ICCAE 2016), pp. 1-23, Taipei, Taiwan, July 2016.

[46] C. S. Teja, T. S. Moturu, G. Y. Kumar, H. A. Khan, G. Y. Kumar, and H. A. Khan, "Effect of fire on prefabricated concrete beam column connections," International Journal of Recent Technology and Engineering, vol. 8, no. 2, pp. 14331436, 2019.

[47] L. Chen and Y. C. Wang, "Methods of improving survivability of steel beam/column connections in fire," Journal of Constructional Steel Research, vol. 79, pp. 127-139, 2012.

[48] R. Aseeva, B. Serkov, and A. Sivenkov, Fire Behavior and Fire Protection in Timber Buildings, Springer Series in Wood Science, New York, NY, USA, 2014.

[49] P. Palma and A. Frangi, "Modelling the fire resistance of steelto-timber dowelled connections loaded perpendicularly to the grain," Fire Safety Journal, vol. 107, pp. 54-74, 2019.

[50] D. Brandon, C. Maluk, M. P. Ansell et al., "Fire performance of metal-free timber connections," Construction Material, vol. 168, pp. 173-186, 2015.

[51] D. Brandon, M. Ansell, J. Bregulla, R. Harris, and P. Walker, "Behaviour of non-metallic shear connections in fire," in Proceedings of the WCTE 2014 - World Conference on Timber Engineering, Quebec City, Canada, August 2014.
[52] J. L. Torero, A. Law, and C. Maluk, "Defining the thermal boundary condition for protective structures in fire," Engineering Structures, vol. 149, pp. 104-112, 2017.

[53] J. Gales, C. Maluk, and L. Bisby, "Large-scale Structural Fire Testing-How did we get here, where are we, and where are we going?" in Proceedings of the 15th International conference on experimental mechanics: Fire symposium, Porto, Portugal, July 2012, http://hdl.handle.net/1842/6176.

[54] T. Y. Song, L. H. Han, and Z. Tao, "Performance of steelreinforced concrete beam-to-column joints after exposure to fire," Journal of Structural Engineering, vol. 14210 pages, 2016.

[55] F. F. Feng, H. J. Hwang, and W. J. Yi, "Static and dynamic loading tests for precast concrete moment frames under progressive collapse," Engineering Structures, vol. 213, no. 4, Article ID 110612, 2020.

[56] Y. F. Yang and F. Fu, "Fire resistance of steel beam to square CFST column composite joints using RC slabs: experiments and numerical studies," Fire Safety Journal, vol. 104, pp. 90$108,2019$.

[57] S. Mindess, L. Chen, and D. R. Morgan, "Determination of the first-crack strength and flexural toughness of steel fiberreinforced concrete," Advanced Cement Based Materials, vol. 1, no. 5, pp. 201-208, 1994.

[58] A. J. Hamad and R. J. A. Sldozian, "Flexural and flexural toughness of fiber reinforced concrete-American standard specifications review," GRD Journals- Global Research and Development Journal for Engineering, vol. 4, no. 3, pp. 5-13, 2019.

[59] K. S. Al-Jabri, I. W. Burgess, T. Lennon, and R. J. Plank, "Moment-rotation-temperature curves for semi-rigid joints," Journal of Constructional Steel Research, vol. 61, no. 3, pp. 281-303, 2005.

[60] R. K. Qureshi, N. Elhami-Khorasani, and T. Gernay, "Adaption of active boundary conditions in structural fire testing," Journal of Structure Fire Engineering, vol. 10, no. 4, pp. 504-528, 2019.

[61] C. Maluk, L. Bisby, G. Terrasi, M. Krajcovic, and J. L. Torero, "Novel fire testing methodology: Why, how and what now?" in Proceedings of the Mini Symposium on Performance-based Fire Safety Engineering of Structures as part of the 1st International Conference on Performance, Hong Kong, December 2012.

[62] V. K. R. Kodur and A. Agrawal, “An approach for evaluating residual capacity of reinforced concrete beams exposed to fire," Engineering Structures, vol. 110, pp. 293-306, 2016.

[63] European Committee For Standardization, Eurocode 2: Design of concrete Structures - Part 1-2: General Rules - Structural Fire Design, European Committee For Standardization, Brussels, Belgium, 2011.

[64] European Committee For Standardization, Eurocode 3: Design of Steel Structures - Part 1-2: General Rules - Structural Fire Design, European Committee For Standardization, Brussels, Belgium, 2011.

[65] T. Y. Song, L. H. Han, and B. Uy, "Performance of CFST column to steel beam joints subjected to simulated fire including the cooling phase," Journal of Constructional Steel Research, vol. 66, pp. 591-604, 2010.

[66] T. Y. Song, L. H. Han, and H. X. Yu, “Temperature field analysis of SRC-column to SRC-beam joints subjected to simulated fire including cooling phase," Advances in Structural Engineering, vol. 14, no. 3, pp. 353-366, 2011.

[67] T. B. Chu and Q. V. Truong, "Numerical studies of composite steel-concrete columns under fire conditions including cooling phase," in Proceedings of the Congrès International de 
Géotechnique Ouvrages Structures, Springer, Ho Chi Minh City, Vietnam, pp. 213-223, October 2017.

[68] M. B. Dwaikat and V. K. R. Kodur, "Hydrothermal model for predicting fire-induced spalling in concrete structural systems," Fire Safety Journal, vol. 44, pp. 425-434, 2009.

[69] T. Gernay and J. M. Franssen, "A performance indicator for structures under natural fire," Engineering Structures, vol. 100, pp. 94-103, 2015.

[70] C. K. Kankam and B. Odum-Ewuakye, "Babadua reinforced concrete two-way slabs subjected to concentrated loading," Construction Building Materials, vol. 20, no. 5, pp. 279-285, 2006.

[71] M. T. Audu and O. W. Oseni, "First crack and yield load of Fanpalm reinforced concrete slabs," International Journal of Science and Research, vol. 4, no. 11, pp. 1979-1981, 2015.

[72] B. Merci and P. Vandevelde, "Experimental study of natural roof ventilation in full-scale enclosure fire tests in a small compartment," Fire Safety Journal, vol. 42, pp. 523-535, 2007.

[73] A. B. Abd Rahman, C. D. P. Leong, A. Saim, and M. H. Osman, "Hybrid beam-to-column connections for precast concrete frames," in Proceedings of the 6th Asia-Pacific Struct. Eng. Constr. Conf. (APSEC 2006), pp. A281-A290, Kuala Lumpur, Malaysia, September 2006.

[74] R. Wróblewski, J. Gierczak, P. Smardz, and A. Kmita, "Fire and collapse modelling of a precast concrete hall," Structure and Infrastructure Engineering, vol. 12, no. 6, pp. 714-729, 2016.

[75] M. Smith and J. Gales, "Connection behaviour in contemporary canadian buildings subjected to real fires," in Proceedings of the SFPE performance based design conference, p. 6p. 6, 2018.

[76] American Society of Civil Engineers, Performance-Based Structural Fire Design: Exemplar Designs of Four Regionally Diverse Buildings Using ASCE 7-16, Appendix E. American Society of Civil Engineers, Honolulu, HI, USA, April 2018.

[77] K. S. Al-Jabri, J. B. Davison, and I. W. Burgess, "Performance of beam-to-column joints in fire-A review," Fire Safety Journal, vol. 43, no. 1, pp. 50-62, 2008. 